\title{
Enlist volunteer corn affects the crop development and seed quality of Enlist soybean
}

\author{
Alcimar Spindola Mazon¹ (1), Joanei Cechin 2,3,* (D), Cristiano Piasecki² (D), Juliano Gazola² (D), \\ Jonas Rodrigo Henckes ${ }^{4}$ (D), Geri Meneghello ${ }^{1}$ (D), Dirceu Agostinetto² (I) \\ 1. Universidade Federal de Pelotas Rớ - Fitotecnia - Ciência e Tecnologia de Sementes - Pelotas (RS), Brazil. \\ 2. Universidade Federal de Pelotas rớr - Fitossanidade - Pelotas (RS), Brazil. \\ 3. Universidade Estadual de Ponta Grossa Rór - Departamento de Fitotecnia e Fitossanidade - Ponta Grossa (PR), Brazil. \\ 4. Universidade Estadual de Maringá Rợ - Fitotecnia - Maringá (PR), Brazil. \\ Received: Jul. 13, 2021 | Accepted: Nov. 3, 2021 \\ Section Editor: Gabriel Constantino Blain \\ *Corresponding author: joaneicechin@yahoo.com.br \\ How to cite: Mazon AS, Cechin J, Piasecki C, Gazola J, Henckes JR, Meneghello G, et al. (2022). Enlist volunteer corn affects the crop \\ development and seed quality of Enlist soybean. Bragantia, 81, e0122. https://doi.org/10.1590/1678-4499.20210207
}

\begin{abstract}
Enlist ${ }^{\mathrm{TM}}$ technology is a new trait on soybean and corn conferring tolerance to auxinic-type (2,4-D choline) and graminicides (aryloxyphenoxypropionates - FOPs) herbicides. However, the occurrence of volunteer corn tolerant to 2,4-D and FOPs can become a significant weed on soybean cropping systems, affecting the crop yield and reducing seed quality. This research aimed to evaluate herbicides to Enlist ${ }^{\mathrm{TM}}$ volunteer corn control and their effects on plant development, crop yield, and physiological seed quality of Enlist ${ }^{\mathrm{TM}}$ soybean. Field experiment was performed in a complete randomized block experimental design with four replicates, using a density of 10 plants· $\mathrm{m}^{-2}$ of Enlist ${ }^{\mathrm{TM}}$ volunteer corn. Treatments consisted of herbicides applied at 3-4-leaves stage of volunteer corn with haloxyfop-P-methyl, clethodim, pinoxaden, cloransulam-methyl and imazethapyr regarding to a control with and without volunteer corn. The development and yield components of Enlist ${ }^{\mathrm{TM}}$ soybean were evaluated and physiological seed testing performed on soybean's seeds. Clethodim controlled Enlist ${ }^{\mathrm{TM}}$ volunteer corn, whereas haloxyfop-P-methyl, pinoxaden, and cloransulam-methyl showed insufficient control levels (30-35\%) at 30 days after spray. Imazethapyr exhibited $84 \%$ of control of Enlist ${ }^{\mathrm{TM}}$ volunteer corn and injured the Enlist ${ }^{\mathrm{TM}}$ soybean, affecting its seed viability. Enlist ${ }^{\mathrm{TM}}$ volunteer corn interferences negatively the soybean crop yield, yield components, and affects the plant development pattern.
\end{abstract} Key words: acetyl CoA carboxylase inhibiting herbicides, synthetic auxins, weed interference, seed analysis.

\section{INTRODUCTION}

Soybean [Glycine max (L.) Merrill] is the leading agricultural commodity for Brazilian farmers and trade balance, with major exported volumes that meet $29 \%$ of the world's demand (Giraudo 2020). Good soybean management practices, including high-quality seeds and adequate weed control, are essential to increase the crop yield. For example, weed interference can reduce up to $94 \%$ of soybean yield, depending on the weed species and coexistence period (Zandoná et al. 2018). In contrast, seeds with higher quality can increase approximately $15 \%$ the grain yield (Ebone et al. 2020). Otherwise, cropweed interference can reduce seed quality due to physiological changes and its effects on photoassimilates production fill seeds (Carciochi et al. 2019). Roundup Ready ${ }^{\oplus}$ technology developed in the 1990s for soybean and available later for corn contributed to weed control, reducing costs, and increasing the grain yield (Benbrook 2016). After the commercial release, grain yield increased approximately 4-fold, whereas herbicides use reduced 75\% between 1995 to 2013 (Benbrook 2016). This scenario based on repeated glyphosate application favored the selection of weed-resistant populations, and new traits with herbicide-resistance can provide new management strategies, aiming the control of weed herbicide-resistant populations (Duke 2020). 
Enlist ${ }^{\mathrm{TM}}$ technology is a new tool available for farmers in several countries to control glyphosate-resistant broadleaf weeds, conferring tolerance to 2,4-dichlorophenoxyacetic acid (2,4-D choline), glyphosate, and ammonium-glufosinate herbicides (Wright et al. 2010; Skelton et al. 2017). The tolerance to 2,4-D choline was obtained by the insertion of the aryloxyalkanoate dioxygenase ( $A A D$-12 V1) coding-gene. Thus, $A A D$-12 protein catalyzes the conversion of 2,4-D to 2,4-dichlorophenol (2,4-DCP) using sugar molecule to detoxify it into a non-phytotoxic compounds (Wright et al. 2010). On the other hand, the double mutant of 5-enolpyruvylshikimate 3-phosphate synthase (EPSPs) and phosphinothricin acetyltransferase (pat) confers tolerance to glyphosate and ammonium-glufosinate, respectively (Wright et al. 2010). Furthermore, Enlist ${ }^{\mathrm{mt}}$ technology can be found in corn from the insertion of the $A A D-1 V 3$ gene that encodes the $A A D-1$ protein. This protein catalyzes the breakage of the chemical bond between oxygen and carbon, conferring tolerance to acetyl CoA carboxylase (ACCase) herbicides of the aryloxyphenoxypropionates (FOPs) chemical group. It allows the control of grasses in Enlist corn's post-emergence (Gonzalez et al. 2018).

In several countries, especially in Brazil, agricultural production systems cultivate soybean after corn in the same season, a practice known as off-season (Petter et al. 2015). In this case, propagules (seeds and kernels) of Enlist ${ }^{\mathrm{TM}}$ corn can be lost during the harvest, originating individual or clumps of volunteer corn for the subsequent crop, reducing the soybean yield (Marca et al. 2015; Petter et al. 2015). The highly competitive ability of volunteer corn was reported in Roundup Ready ${ }^{\otimes}$ soybean with an economic threshold for individual plants of 0.45 plants $\cdot \mathrm{m}^{-2}$ and approximated to zero for clumps (Piasecki and Rizzardi 2018). Alternative chemical control includes ACCase inhibiting herbicides performed during the initial development stages $\left(\mathrm{V}_{2}-\mathrm{V}_{4}\right)$ to ensure adequate control (Pertile et al. 2018).

Considering the negative effects of crop-weed interference, seed's physiological quality can also be affected due to the physiological changes and lower photoassimilates translocation for the seeds, reducing the 1,000-seed weight and amount of reserves and proteins (Marcos-Filho 2015). Volunteer corn plants are undesirability in soybean, especially in scenarios with an increase of glyphosate-resistant and greater Enlist ${ }^{\mathrm{TM}}$ technology adoption. Thus, approaches are needed to evaluate herbicides effectivenes in Enlist ${ }^{\mathrm{TM}}$ volunteer corn control and measuring the interference effects on plant development and seed quality of Enlist ${ }^{\mathrm{TM}}$ soybean.

This research aimed to evaluate herbicides to control Enlist ${ }^{\mathrm{TM}}$ volunteer corn and their effects on plant development, crop yield, and physiological seed quality of Enlist ${ }^{\mathrm{TM}}$ soybean.

\section{MATERIAL AND METHODS}

Field experiment (geographic coordinates: $31^{\circ} 80^{\prime} 01^{\prime \prime}$, 52 5050'38'W, and $12 \mathrm{~m}$ above the sea) was carried out during the 2016/17 and 2017/18 summer growing season (Figure 1 - envirommnetal conditions), using a randomized complete block experimental design with four repetitions. The field soil was classified as Endoaquult (USDA Soil Taxonomy) and has the following characteristics performed at 0-10 cm layer depth: $\mathrm{pH}=5.6$, organic matter $=1.5 \%$, clay $=16 \%, \mathrm{CEC}_{\mathrm{pH} 7}=6.7 \mathrm{cmolc} \cdot \mathrm{dm}^{-3}$, $\mathrm{Al}^{3+}=3.1 \mathrm{cmolc} \cdot \mathrm{dm}^{-3}, \mathrm{Ca}^{+2}=6.6 \mathrm{mmolc} \cdot \mathrm{dm}^{-3} ; \mathrm{Mg}^{+2}=2.7 \mathrm{cmolc} \cdot \mathrm{dm}^{-3}, \mathrm{~K}^{+}=0.23 \mathrm{mg} \cdot \mathrm{dm}^{-3}$, and $\mathrm{P}=9.9 \mathrm{~g} \cdot \mathrm{dm}^{-3} \cdot$ For the winter growing season, black oat was used as a cover crop that was burndown with glyphosate applied 30 days before the sowing at a rate of $1,080 \mathrm{~g}$ ae $\cdot \mathrm{ha}^{-1}$.

Enlist ${ }^{\mathrm{TM}}$ soybean (DAS-44406-6 lineage) was sowed at 32 plants $\cdot \mathrm{m}^{-2}$ in plots of $7.2 \mathrm{~m}^{2}, 45$-cm rows spaced. Seeds were treated with pyraclostrobin + thiophanate-methyl + fipronil (Standak ${ }^{\odot}$ Top) at the rate of $2 \mathrm{~mL}$ of commercial product for each $\mathrm{kg}$ of seed, and inoculated with Bradyrhizobium japonicum bacterium to nitrogen fixation. Base fertilization was calculated in accordance with the recommendations for the soybean crop, using $350 \mathrm{~kg} \cdot \mathrm{ha}^{-1}$ of nitrogen, phosphorous, and potassium (NPK) formulation 02-20-20. $\mathrm{F}_{2}$ progeny of Enlist ${ }^{\mathrm{TM}}$ volunteer corn (DAS-40278-9 lineage) was randomly sown and standardized at 10 individual volunteer plants $\mathrm{m}^{-2}$. Enlist ${ }^{\mathrm{TM}}$ seeds were obtained from Corteva Agriscience company with required authorization.

Post-emergent herbicides to control Enlist ${ }^{\mathrm{TM}}$ volunteer corn included haloxyfop-P-methyl (60 $\mathrm{g}$ ai.ha ${ }^{-1}$, Verdict ${ }^{\oplus}$ Max, Corteva, Brazil), clethodim (108 g ai. ha ${ }^{-1}$, Select ${ }^{\oplus} 240$ EC, UPL, Brazil), pinoxaden (30 g ai.ha ${ }^{-1}$, Axial ${ }^{\oplus}$, Syngenta, Argentina), cloransulam-methyl (40 g ai.ha ${ }^{-1}$, Pacto ${ }^{\oplus}$, Corteva, Brazil), and imazethapyr (100 g ai.ha ${ }^{-1}$, Vezir ${ }^{\oplus}$, ADAMA Agricultural 


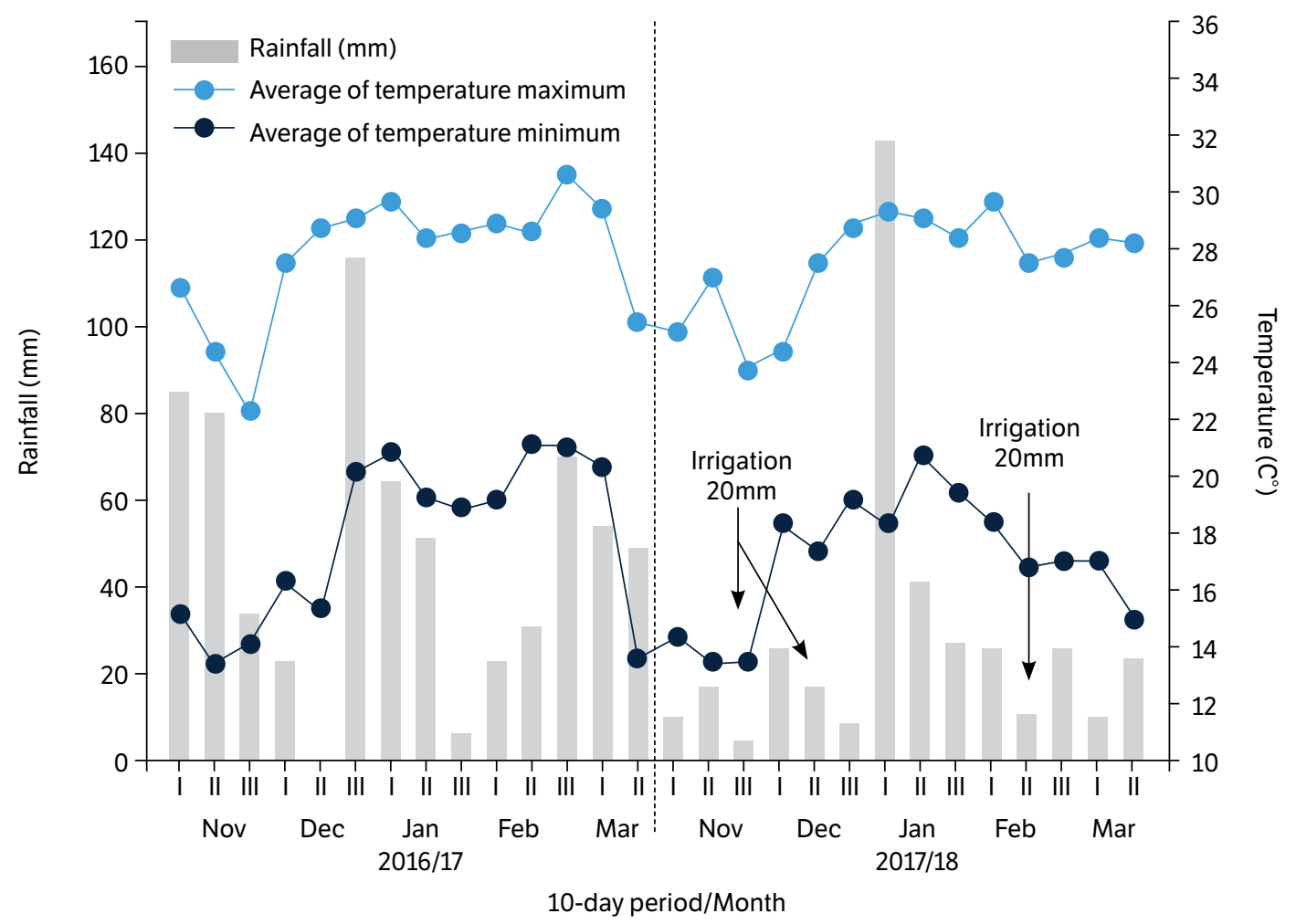

Source: Estação Meteorológica da Empresa Brasileira de Pesquisa Agropecuária (Embrapa) Terras Baixas, Capão do Leão (RS), Brazil.

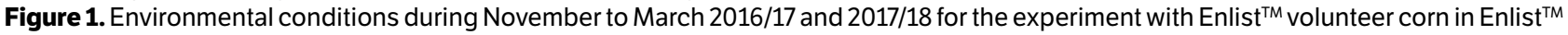
soybean measured in each 10-day period. In the second year, three irrigations were performed with $20 \mathrm{~mm}$ each in November, December, and February to enhance the soil moisture content.

Solutions, Brazil) compared to the control without and with Enlist ${ }^{\mathrm{TM}}$ volunteer corn. Specific adjuvant was added for each herbicide, in accordance with the manufacturer's recommendations. Herbicides were applied at $V_{3}-V_{4}$ phenological stages of corn, using a $\mathrm{CO}_{2}$ backpack sprayer equipped with four TeeJet AXI 110.15 spray nozzles, spaced at $0.5 \mathrm{~m}$ calibrated to deliver $120 \mathrm{~L} \cdot \mathrm{ha}^{-1}$. The herbicide application was performed at air temperature of $21^{\circ} \mathrm{C}, 59 \%$ relative air humidity, and wind speed of $2.9 \mathrm{~km} \cdot \mathrm{h}^{-1}$. After herbicide application, rainfall was not reported for seven days.

The control of Enlist ${ }^{\mathrm{TM}}$ volunteer corn plants and Enlist ${ }^{\mathrm{TM}}$ soybean sensitivity were evaluated at 10,20 , and 30 days after application (DAA), through visual assessments from 0 to $100 \%-0 \%$ refers to the absence of phytotoxic effects and $100 \%$ to the complete death of the plants. Enlist ${ }^{\mathrm{TM}}$ soybean plant height (PH), height of first pod insertion (HFPI), number of internodes and braches per plant (INP and BNP) were measured at the full maturity. Soybean $\mathrm{PH}$ was measured with a rule from the soil surface to the tip of the last fully expanded leaf in 10 random plants per plot. Enlist ${ }^{\mathrm{TM}}$ soybean was harvested in an area of $3.5 \mathrm{~m}^{2}$ to calculate the grain yield, and 10 plants were used to quantify the yield components (pods number per plant, seeds per plant, 1,000-seed weight). Samples were threshed, cleaned, and weighed in a precision analytical balance, at a standard seeds moisture of $13 \%$. The 1,000-seed weight was performed after samples cleaned, using eight subsamples containing 100 seeds each. A sample portion from each plot was stored in a cold chamber at $10^{\circ} \mathrm{C}$ for 30 days to perform the seed physiological analysis.

Seed testing to evaluate the physiological quality was performed at a seed laboratory, using a completely randomized design with four replicates of 50 Enlist $^{\mathrm{TM}}$ soybean seeds each. Seed physiological analysis was measured by the germination test and first germination count, accelerated aging, tetrazolium seed testing, and field emergence, following the official methodology described in the Brazilian rules for seed testing (Brasil 2009). For germination testing (GT), seeds were distributed over two sheets of germitest paper previously moistened with distilled water at an amount equivalent to 2.5 -fold the paperweight, and placed in a biochemical oxygen chamber demand (BOD) regulated at $25^{\circ} \mathrm{C}$ and $12 \mathrm{~h}$ in light. The first germination count (FGC) of normal seedlings was performed at five days after setting up the germination test. In contrast, 
the final germination was obtained at eight days after, with the values expressed in percentage. Accelerated aging (AA) was carried out in transparent boxes, using 200 seeds distributed in a single layer under lifted wire mesh. The boxes were filled with $40 \mathrm{~mL}$ of distilled water, closed and transferred to a BOD at $41^{\circ} \mathrm{C}$ for $72 \mathrm{~h}$ (Brasil 2009). Afterwards, the seed germination test was conducted equally of the FGC methodology.

Tetrazolium seed testing (TST) was performed using two subsamples of 50 seeds each by repetition. Seeds were put in a paper previously moistened with distilled water for $16 \mathrm{~h}$ and placed in a germination camera at $25^{\circ} \mathrm{C}$. Then, seeds were transferred to glass cups with a $0.075 \%$ tetrazolium solution, maintained for $3 \mathrm{~h}$ in the dark inside an incubator at $40^{\circ} \mathrm{C}$ to form the embryo color. Seed viability and vigor were evaluated in a magnifying glass, with values expressed in percentage. Field emergence (FE) under natural conditions was carried out in raised beds, using two subsamples of 50 seeds each by repetition. Soybean seeds were sown manually to a depth of $2 \mathrm{~cm}$ in a wet soil. The normal seedlings count was evaluated 21 days after sown, with values expressed in percentage (Nakagawa 1999).

Data were analyzed for normality by the Shapiro-Wilk test and subjected to variance analysis $(\mathrm{p}<0.05)$. When significant, means were compared by Duncan's test $(\mathrm{p}<0.05)$ using the Statistical Analysis System software (SAS, version 9.0). Data were analyzed together due to absence of significant differences between growing seasons.

\section{RESULTS AND DISCUSSION}

Insuficient control of Enlist ${ }^{\mathrm{TM}}$ volunteer corn was found after application of haloxyfop-P-methyl, pinoxaden, and cloransulam-methyl herbicides, regardless of the evaluated period, with values lower than $35 \%$ (Table 1). Clethodim exhibited the highest control of Enlist ${ }^{\mathrm{TM}}$ volunteer corn with levels greater than $91 \%$ during the evaluated period, whereas imazethapyr controlled $84 \%$ of volunteer corn at 30 DAA (Table 1). Studies have been reported the application of ACCase

Table 1. Control (\%) of Enlist ${ }^{\top \mathrm{M}}$ volunteer corn and injury (\%) on Enlist soybean after exposure to post-emergence herbicides evaluated at 10, 20 and 30 DAA. 2021.

\begin{tabular}{|c|c|c|c|c|}
\hline \multirow{2}{*}{ Herbicide treatment } & \multirow{2}{*}{$\begin{array}{c}\text { Rate } \\
\left(\mathrm{g} \text { ai }^{-} \mathrm{ha}^{-1}\right)\end{array}$} & \multicolumn{3}{|c|}{ Control (\%) } \\
\hline & & 10 DAA & 20 DAA & 30 DAA \\
\hline Control with volunteer corn & - & $0.0 e^{\star}$ & $0.0 \mathrm{e}$ & $0.0 \mathrm{e}$ \\
\hline Control without volunteer corn & - & $100 \mathrm{a}$ & $100 \mathrm{a}$ & $100 \mathrm{a}$ \\
\hline Haloxyfop-P-methyl & 60 & $8.0 \mathrm{e}$ & $12 \mathrm{~d}$ & $14 \mathrm{~d}$ \\
\hline Clethodim & 108 & $91 b$ & $98 a$ & $100 \mathrm{a}$ \\
\hline Pinoxaden & 30 & $24 d$ & $19 \mathrm{~d}$ & $16 \mathrm{~d}$ \\
\hline Cloransulam-methyl & 40 & $30 \mathrm{~d}$ & $32 c$ & $35 c$ \\
\hline Imazetapyr & 100 & $60 c$ & $87 b$ & $84 \mathrm{~b}$ \\
\hline Coefficient of variation (\%) & & 5.1 & 3.3 & 4.8 \\
\hline Herbicide treatment & $\begin{array}{c}\text { Rate } \\
\left(\mathrm{g} \text { ai-ha }{ }^{-1}\right)\end{array}$ & \multicolumn{3}{|c|}{ Enlist soybean injury (\%) } \\
\hline Control with volunteer corn & - & $0.0 \mathrm{c}$ & $0.0 \mathrm{c}$ & $0.0 \mathrm{c}$ \\
\hline Control without volunteer corn & - & $0.0 \mathrm{c}$ & $0.0 \mathrm{c}$ & $0.0 \mathrm{c}$ \\
\hline Haloxyfop-p-methyl & 60 & $3.0 \mathrm{c}$ & $0.0 \mathrm{c}$ & $0.0 \mathrm{c}$ \\
\hline Clethodim & 108 & $5.0 \mathrm{c}$ & $2.0 \mathrm{c}$ & $0.0 \mathrm{c}$ \\
\hline Pinoxaden & 30 & $5.0 \mathrm{c}$ & $1.0 \mathrm{c}$ & $0.0 \mathrm{c}$ \\
\hline Cloransulam-methyl & 40 & $10 \mathrm{~b}$ & $8.0 \mathrm{~b}$ & $6.0 \mathrm{~b}$ \\
\hline Imazetapyr & 100 & $19 a$ & $16 a$ & $13 a$ \\
\hline Coefficient of variation (\%) & & 19.9 & 11.5 & 8.1 \\
\hline
\end{tabular}

*Same lowercase letters in the column did not differ by Duncan's test $(p<0.05)$; DAA: days after application. 
inhibiting herbicides to control volunteer corn, mainly when performed at $\mathrm{V}_{2}-\mathrm{V}_{3}$ phenological stages to ensure better control levels (Chahal and Jhala 2015; Pertile et al. 2018). The reduced control of Enlist ${ }^{\mathrm{TM}}$ volunteer corn to haloxyfop-P-methyl was expected because its tolerance to that herbicide due to $A A D-1$ enzyme insertion confers tolerance to AOPPs herbicides, reducing the herbicidal damage (Wright et al. 2010; Chekan et al. 2019). Reduced control was also found to pinoxaden, an active ingredient from phenylpyrazolin chemical group (DEN), controlling only $65 \%$ of the Enlist ${ }^{\mathrm{TM}}$ volunteer corn at 28 DAA (Striegel et al. 2020), suggesting that the $A A D-1$ enzyme can also reduce the sensibility of Enlist ${ }^{\mathrm{TM}}$ corn to DEN. In contrast, imazethapyr exhibited $84 \%$ control of glyphosate-volunteer corn at 30 DAA (Marca et al. 2015).

Despite providing $84 \%$ of control, imazethapyr injured the Enlist ${ }^{\mathrm{TM}}$ soybean, with values up to $19 \%$. On the other hand, haloxyfop-P-methyl, pinoxaden, and clethodim applied at labeled rate did not exhibit significant injury, with values lower than 5\% (Table 1). The specific activity of ACCase-inhibiting herbicides on grasses occurs due to their selective inhibition of homomeric plastidic ACCase only found in monocots. In contrast, heteromeric plastidic or homomeric cytosolic forms found in soybean and other dicots are not inhibited by ACCase inhibitors (Kukorelli et al. 2013). On the other hand, cloransulam-methyl and imazethapyr inhibit the enzyme acetolactate synthase (ALS), dependent on metabolic degradation to provide rapid inactivation of herbicide molecule. Thus, lower injury levels of these herbicides in soybean involve differential activity of cytochrome $\mathrm{P}_{450}$ enzymes complex followed by glutathione conjugation, leading to differential tolerance between soybean and weeds (Nandula et al. 2019).

Additionally, volunteer corn plants, when present in soybean crops, can interfere and cause damage to the plant development. Thus, chemical management of Enlist ${ }^{\mathrm{TM}}$ volunteer corn has greater importance to reduce the competition and ensure better conditions for soybean development. While the resources are limited in agricultural fields, crop-weed competition can change the light capture and perception in response to shading, affecting physiological processes and their development (Mckenzie-Gopsill et al. 2016). The presence of Enlist ${ }^{\mathrm{TM}}$ volunteer corn increased the Enlist ${ }^{\mathrm{TM}}$ soybean $\mathrm{PH}$, especially for the treatments with reduced control by post-emergence herbicides evaluated (Table 2).

Table 2. Morphological parameters and yield components of Enlist ${ }^{\mathrm{TM}}$ soybean after the interference of Enlist ${ }^{\mathrm{TM}}$ volunteer corn. 2021.

\begin{tabular}{|c|c|c|c|c|c|}
\hline \multirow{2}{*}{ Herbicide treatment } & \multirow{2}{*}{$\begin{array}{c}\text { Rate } \\
\left(\mathrm{g} \text { ai } \mathrm{ha}^{-1}\right)\end{array}$} & \multicolumn{4}{|c|}{ Morphological parameters } \\
\hline & & $\mathrm{PH}(\mathrm{m})$ & HFPI (cm) & INP & BNP \\
\hline Control with volunteer corn & - & $1.43 a^{*}$ & $29.8 a$ & $17.2 \mathrm{~b}$ & $2.6 \mathrm{c}$ \\
\hline Control without volunteer corn & - & $1.25 \mathrm{c}$ & $28.4 \mathrm{a}$ & $21.1 \mathrm{a}$ & $4.0 \mathrm{a}$ \\
\hline Haloxyfop-P-methyl & 60 & $1.42 \mathrm{a}$ & $24.6 \mathrm{~b}$ & $17.1 \mathrm{~b}$ & $2.0 \mathrm{c}$ \\
\hline Clethodim & 108 & $1.33 \mathrm{~b}$ & $23.9 \mathrm{~b}$ & $22.4 \mathrm{a}$ & $4.2 \mathrm{a}$ \\
\hline Pinoxaden & 30 & $1.46 \mathrm{a}$ & $26.0 \mathrm{~b}$ & $17.5 \mathrm{~b}$ & $2.4 \mathrm{c}$ \\
\hline Cloransulam-methyl & 40 & $1.37 \mathrm{~b}$ & $22.8 \mathrm{c}$ & $18.9 \mathrm{~b}$ & $2.2 \mathrm{c}$ \\
\hline Imazetapyr & 100 & $1.35 \mathrm{~b}$ & $22.1 \mathrm{c}$ & $22.3 \mathrm{a}$ & $3.6 \mathrm{~b}$ \\
\hline Coefficient of variation (\%) & & 5.8 & 5.3 & 7.2 & 15.6 \\
\hline \multirow{2}{*}{ Herbicide treatment } & \multirow{2}{*}{$\begin{array}{c}\text { Rate } \\
\left(\mathrm{g} \text { ai } \cdot \mathrm{ha}^{-1}\right)\end{array}$} & \multicolumn{4}{|c|}{ Soybean yield components } \\
\hline & & PNP & SP & SW (g) & GY $\left(\mathbf{k g} \cdot \mathrm{ha}^{-1}\right)$ \\
\hline Control with volunteer corn & - & $27.9 c^{\star}$ & $71 c$ & $179.3 \mathrm{a}$ & $868.5 \mathrm{c}$ \\
\hline Control without volunteer corn & - & $86.3 \mathrm{a}$ & $196 \mathrm{a}$ & $166.4 \mathrm{c}$ & $3536.1 \mathrm{a}$ \\
\hline Haloxyfop-P-methyl & 60 & $29.3 c$ & $63 c$ & $176.1 \mathrm{a}$ & $954.1 \mathrm{c}$ \\
\hline Clethodim & 108 & $89.8 \mathrm{a}$ & $204 a$ & $162.8 \mathrm{c}$ & $3268.4 \mathrm{a}$ \\
\hline Pinoxaden & 30 & $30.2 \mathrm{c}$ & $66 c$ & $179.2 \mathrm{a}$ & $839.8 \mathrm{c}$ \\
\hline Cloransulam-methyl & 40 & $31.8 \mathrm{c}$ & $70 \mathrm{c}$ & 178.9 a & $1172.6 \mathrm{c}$ \\
\hline Imazetapyr & 100 & $61.4 \mathrm{~b}$ & $138 \mathrm{~b}$ & $171.5 \mathrm{~b}$ & $2277.4 \mathrm{~b}$ \\
\hline Coefficient of variation (\%) & & 26.7 & 28.1 & 3.6 & 21.1 \\
\hline
\end{tabular}

*Same lowercase letters in the column did not differ by Duncan's test ( $p<0.05)$; PH: plant height; HFPI: height of first pod insertion; INP: internodes number per plant; BNP: branches number per plant; PNP: pod number per plant; SP: seeds per plant; SW: 1,000-seed weight; GY: grain yield. 
Enlist $^{\mathrm{TM}}$ soybean treated with haloxyfop-P-methyl and pinoxaden showed $\mathrm{PH}$ of $15 \%$ greater than control without Enlist ${ }^{\mathrm{TM}}$ volunteer corn. Additionally, $\mathrm{PH}$ of Enlist ${ }^{\mathrm{TM}}$ soybean was $10 \%$ higher after exposure to cloransulam-methyl, imazethapyr, and clethodim herbicides than control (weed-free), demonstrating the need for adequate management to avoid the adverse effects of corn-soybean competition. The coexistence of glyphosate-tolerant volunteer corn in competition with soybean increased $16 \%$ the $\mathrm{PH}$, especially on varieties with short growth cycle and control performed later (Caratti et al. 2018). Morphological and physiological changes due to the neighbor's competition can occur between species in response to the light perception and its effects on antioxidant machinery, affecting the architecture of the canopy and photosynthetic efficacy (Benemann et al. 2020). At prior to harvest, HFPI of Enlist ${ }^{\mathrm{TM}}$ soybean was not affected significantly by corn-competition, with values greater than $28.4 \mathrm{~cm}$ (Table 2). In contrast, all herbicides applied on Enlist ${ }^{\mathrm{TM}}$ soybean reduced the HFPI, especially the imazethapyr, with values $28 \%$ lower than the control without Enlist ${ }^{\mathrm{TM}}$ volunteer corn and herbicide application (Table 2). HFPI is an important parameter used to regulate the harvester platform's cutting height to avoid grain losses, requiring a minimum pod height to cut-off greater than $15 \mathrm{~cm}$ in moderately declined fields (Andrade et al. 2016). Furthermore, herbicides can reduce the first pod's height, especially when it triggers high injury levels. For example, fomesafen and cloransulam-methyl were applied on Roundup Ready soybean at a labeled rate reduced 22\% the HFPI (Novakoski et al. 2020).

Other morphological changes can occur due to competition and injury caused by herbicides, affecting the development. Enlist $^{\mathrm{TM}}$ soybean without competition caused by volunteer Enlist ${ }^{\mathrm{TM}}$ showed greater INP and BNP values. Plots treated with clethodim exhibited INP and BNP values statistically equal to control without volunteer corn (Table 2). However, lower control obtained by haloxyfop-P-methyl, pinoxaden, and cloransulam-methyl herbicides increased the corn-soybean interference effects and reduced the INP and BNP strongly, with values 18 and 55\% lower than Enlist ${ }^{\mathrm{TM}}$ soybean without Enlist $^{\mathrm{TM}}$ volunteer corn (Table 2). The corn-soybean competition due to inadequate control affects reproductive structures' development, with values up to $80 \%$ lower depending on the soybean cultivar used (Caratti et al. 2018). These results show the importance of ensuring highest levels of control of Enlist ${ }^{\mathrm{TM}}$ volunteer corn, reducing the interference, and protecting the grain yield potential.

Evaluating the grain yield components, Enlist ${ }^{\mathrm{TM}}$ soybean without Enlist ${ }^{\mathrm{TM}}$ volunteer corn or treated with clethodim showed higher PNP and SP, with values up to $68 \%$ greater than control with Enlist ${ }^{\mathrm{TM}}$ volunteer corn and other herbicides evaluated (Table 2). However, the SW of Enlist ${ }^{\mathrm{TM}}$ soybean without volunteer corn was 6\% lower than control with volunteer Enlist $^{\mathrm{TM}}$ corn or treated with haloxyfop-P-methyl (Table 2). Several results have reported substantial pods reduction in soybean under stressors agents like weed competition (Caratti et al. 2018; Piasecki and Rizzardi, 2018). An unfortunate outcome of control can favor the weed development, affecting the crop plant growth and reducing the available resources to photoassimilates production (Baucom 2019). The higher corn height reduces the light interception by soybean and changes the red:far-red ration detected by plant phytochromes, affecting the resource partitioning (Ballaré 2014). Crop-weed competition can increase oxidative stress and up-regulate the expression of photosynthetic apparatus genes (Benemann et al. 2020). Additionally, morphological changes under competition in soybean include lower internodes and branches number, reducing the reproductive buds, pods, and seeds produced per plant (Harre and Young 2020).

Enlist $^{\mathrm{TM}}$ soybean with Enlist ${ }^{\mathrm{TM}}$ volunteer corn showed an average grain yield of $73 \%$ lower than the control without volunteer plants and 70\% lower than the Enlist ${ }^{\mathrm{TM}}$ soybean treated with clethodim (Table 2). Furthermore, plots managed with imazethapyr controlled only $84 \%$ of the Enlist ${ }^{\mathrm{TM}}$ volunteer corn, reducing $36 \%$ of the soybean grain yield compared to the control, demonstrating that lower control levels can reduce the grain yield due to greater ability competitive (Table 2). Pertile et al. (2018) reported the higher competitive potential of Roundup Ready ${ }^{\circ}$ volunteer corn on soybean, reducing the grain yield at low densities. Thus, Enlist ${ }^{\mathrm{TM}}$ soybean grain yield reflected the level of Enlist ${ }^{\mathrm{TM}}$ volunteer corn control, in which the clethodim herbicide provided adequate control in comparison of haloxyfop-P-ethyl, pinoxaden, imazethapyr, and cloransulam-methyl. Due to competition, the restricted growing conditions also limit the plant's ability to support seed demand, reducing the total photoassimilates and threshold values of the plant to set seeds produced. In contrast, the seedseed partitioning can cause penalties for the seed weight, because it would have resource-limited during the grain filling (Carciochi et al. 2019). In agricultural systems, adverse effects of weed interference are broadly known, causing strong reduction of the grain yield, especially when the weed management is inadequate during the initial crop development. 
Seed physiological quality of Enlist ${ }^{\mathrm{TM}}$ soybean was affected negatively due to the interference caused by volunteer plants, with G and FCC values 5\% lower compared to the control without volunteer corn (Table 3). Similarly, plots treated with pinoxaden and cloransulam-methyl exhibited $G$ values greater than $97 \%$, whereas Enlist ${ }^{\mathrm{TM}}$ soybean was subjected to clethodim, pinoxaden, and haloxyfop-P-methyl herbicides and showed FCC values greater than $83 \%$ (Table 3). Lower soybean nutrient accumulation can be affected by weed competition, causing the lowest grain yield and seed weight (Harre and Young 2020). On the other hand, seeds with a larger size and weight can show greater seed germination and vigor than smaller seeds (Derre et al. 2017). Thus, seeds with higher reserves amount available to embryo development are essential to ensure the seedling establishment, good stand uniformity, and greater grain yield (Ebone et al. 2020). Although the FCC indicates the seed vigor, other deterioration processes can reduce the germination and vigor, generally identified through more consistent physiological seed testing (Kandasamy et al. 2020).

Based on AA and FE testing, Enlist ${ }^{\mathrm{TM}}$ soybean treated with haloxyfop-P-methyl, pinoxaden, and clethodim herbicides showed significant germination percentage, with values greater than $94 \%$, and statistically similar to control without Enlist ${ }^{\mathrm{TM}}$ volunteer corn (Table 3). However, imazethapyr and cloransulam-methyl applied on Enlist ${ }^{\mathrm{TM}}$ soybean reduced the AA, whereas imazethapyr herbicide affected negatively the FE, reducing approximately 5\% compared to the control (Table 3 ). Larger seed sizes have better embryo formation and significant reserve amounts, ensuring the successful emergence of seedlings (Derre et al. 2017). During the soybean seed germination, several metabolic proteins play a role-key to mobilize the reserves, especially in the carbohydrate metabolism and redox processes (Han et al. 2013), essential steps to begin the germination. In this way, seed vigor is a critical factor determining the initial seedling development, and ensures the initial plant-stand stablishments (Ebone et al. 2020), a key-point to enhance the grain yield.

Evaluating the physiological parameters by TZ testing, vigor and viability of Enlist ${ }^{\mathrm{TM}}$ soybean were elevated to all herbicide treatments, except to imazethapyr, with values greater than $94 \%$ (Table 3 ). The lowest values of vigor

Table 3. Physiological seeds quality of Enlist soybean evaluated by germination (G), first germination count (FGC), accelerated aging (AA), field emergence (FE), and tetrazolium testing after herbicide treatment to control of Enlist ${ }^{\mathrm{TM}}$ volunteer corn. 2021.

\begin{tabular}{|c|c|c|c|c|c|}
\hline Herbicide treatment & $\begin{array}{c}\text { Rate } \\
\left(\mathrm{g} \text { ai } \mathrm{ha}^{-1}\right)\end{array}$ & G (\%) & FCC (\%) & AA (\%) & FE (\%) \\
\hline Control with volunteer corn & - & $92 b^{\star}$ & $79 \mathrm{~b}$ & $92 \mathrm{~b}$ & $95 \mathrm{~b}$ \\
\hline Control without volunteer corn & - & $97 a$ & $84 a$ & $95 a$ & $99 a$ \\
\hline Haloxyfop-P-methyl & 60 & $93 \mathrm{~b}$ & $86 a$ & $95 a$ & $99 a$ \\
\hline Clethodim & 108 & $92 \mathrm{~b}$ & $83 a$ & $94 a$ & $97 a$ \\
\hline Pinoxaden & 30 & $98 a$ & $86 a$ & $94 a$ & $99 a$ \\
\hline Cloransulam-methyl & 40 & $97 a$ & $76 \mathrm{~b}$ & $90 \mathrm{~b}$ & $98 a$ \\
\hline Imazetapyr & 100 & $95 a b$ & $73 b$ & $90 \mathrm{~b}$ & $94 \mathrm{~b}$ \\
\hline Coefficient of variation (\%) & & 1.8 & 7.1 & 2.7 & 2.0 \\
\hline \multirow{2}{*}{ Herbicide treatment } & & \multirow{2}{*}{$\begin{array}{c}\text { Rate } \\
\left(\mathrm{g} \text { ai } \mathrm{ha}^{-1}\right)\end{array}$} & \multicolumn{3}{|c|}{ Tetrazolium testing (\%) } \\
\hline & & & & & Viability \\
\hline Control with volunteer corn & & - & & & $96 a$ \\
\hline Control without volunteer corn & & - & & & $98 a$ \\
\hline Haloxyfop-P-methyl & & 60 & & & $99 a$ \\
\hline Clethodim & & 108 & & & $98 a$ \\
\hline Pinoxaden & & 30 & & & $99 a$ \\
\hline Cloransulam-methyl & & 40 & & & $98 a$ \\
\hline Imazetapyr & & 100 & & & $91 \mathrm{~b}$ \\
\hline Coefficient of variation (\%) & & & & & 2.8 \\
\hline
\end{tabular}

*Same lowercase letters in the column did not differ by Duncan's test $(p<0.05)$. 
and viability found in Enlist ${ }^{\mathrm{TM}}$ soybean after exposure of imazethapyr possibly occurred by higher injury level of herbicide used to control the Enlist ${ }^{\mathrm{TM}}$ volunteer corn. Similar results were reported in soybean cultivar BRS $382 \mathrm{CV}$ (imidazolinone-tolerant - Cultivance ${ }^{\oplus}$ technology), Coodetec cultivar CD249 STS (sulfonylurea-tolerant soybean STS technology) and Nidera cultivar NA5909RR (glyphosate-tolerant technology) managed in lowland areas, in which greater amount of imazapic+imazapyr herbicide residues from carry over caused significant plant injury and reduced the seeds physiological quality (Agostinetto et al. 2018), demonstrating negative effects of imidazolinone herbicides applied in soybean depending on injury level caused. Although imazethapyr is selective for soybean, the cleavage of ring aromatic from imidazolinones herbicides depends on cultivar differential metabolic ability to rapidly metabolize and inactive the toxic compounds. It involves the enzymatic complex of cytochrome $\mathrm{P}_{450}$ monooxygenases and glutathiones that require adenosine triphospate (ATP) (Tecle et al. 1993). Otherwise, some factors like crop management, stress occurrence, and meteorological conditions during the seed development and maturation can influence seed quality, reducing the vigor (Rao et al. 2017).

According to the present study results, the control of Enlist ${ }^{\mathrm{TM}}$ volunteer corn must be appropriately performed to reduce the interference and protect the grain yield of Enlist ${ }^{\mathrm{TM}}$ soybean, assuring the production of seeds with better physiological quality. The recommended practices to control Enlist ${ }^{\mathrm{TM}}$ volunteer corn include the application of clethodim or other ACCase herbicides from cyclohexanedione (DIMs) chemical group, performed at initial development (up to $\mathrm{V}_{4}$ phenological stage) to provide high control levels and reduce the losses of grain during the harvest, and rotation of the transgenic technologies available inside of the same area.

\section{CONCLUSION}

Clethodim is efficient to control Enlist ${ }^{\mathrm{TM}}$ volunteer corn and selective for Enlist ${ }^{\mathrm{TM}}$ soybean. Haloxyfop-P-methyl, pinoxaden, and cloransulam-methyl do not control Enlist ${ }^{\mathrm{TM}}$ volunteer corn, affecting negatively the Enlist ${ }^{\mathrm{TM}}$ soybean plant development and grain yield, but do not affect the physiological seed quality. Imazethapyr causes significant injury in Enlist ${ }^{\mathrm{TM}}$ soybean, reducing the seed viability by tetrazolium testing.

\section{AUTHORS' CONTRIBUTION}

Conceptualization: Mazon, A. S., Cechin, J., Piasecki, C. and Agostinetto, D.; Methodology: Mazon, A. S., Meneghello, G. and Agostinetto, D.; Investigation: Mazon, A. S., Gazola, J. and Henckes, J. R.; Writing - Original Draft: Mazon, A. S., Cechin J. and Piasecki, C.; Writing - Review and Editing: Cechin, J. and Piasecki, C.; Supervision: Meneghello, G. and Agostinetto, D.

\section{DATA AVAILABILITY STATEMENT}

All dataset were generated and analyzed in the current study.

\section{FUNDING}

Coordenação de Aperfeiçoamento de Pessoal de Nível Superior

[https://doi.org/10.13039/501100002322]

Finace Code 001 
Conselho Nacional de Desenvolvimento Científico e Tecnológico

[https://doi.org/10.13039/501100003593]

Grant No: 308363/2018-3

\section{DISCLOSURE STATEMENT}

The authors declare no conflicts of interest.

\section{ACKNOWLEDGEMENTS}

The authors thank the Universidade Federal de Pelotas for their technical support during the research.

\section{REFERENCES}

Agostinetto, D., Fraga, D. S., Vargas, L., Oliveira, C. B. O., Andres, A. and Villela, F. A. (2018). Response of soybean cultivars in rotation with irrigated rice crops cultivated in Clearfield ${ }^{\circ}$ system. Planta Daninha, 36, e018170991. https://doi.org/10.1590/S0100-83582018360100048 Andrade, F.R., Nóbrega, J.C.A., Zuffo, A.M., Martins Junior, V.P., Rambo, T.P. and Santos, A.S. (2016). Características agronômicas e produtivas da soja cultivada em plantio convencional e cruzado. Revista de Agricultura, 91, 81-91. https://doi.org/10.37856/bja.v91i1.181

Ballaré, C.L. (2014). Light regulation of plant defense. Annual Review in Plant Biology, 65, 335-363. https://doi.org/10.1146/ annurev-arplant-050213-040145

Baucom, R.S. (2019). Evolutionary and ecological insights from herbicide-resistant weeds: what have we learned about plant adaptation, and what is left to uncover? New Phytologist, 223, 68-82. https://doi.org/10.1111/nph.15723

Benbrook, C.M. (2016). Trends in glyphosate herbicide use in the United States and globally. Environmental Science Europe, $28,1-15$. https://doi.org/10.1186/s12302-016-0070-0

Benemann, D.P., Cechin, J., Agostinetto, D. and Vargas, L. (2020). Expression of antioxidant genes and photosynthetic apparatus in the soybean crop in competition with Italian ryegrass biotypes (Lolium multiflorum Lam.). Australian Journal of Crop Science, 14, 718-728. https://doi.org/10.21475/ajcs.20.14.05.p2008

Brasil. Ministério da Agricultura, Pecuária e Abastecimento. (2009). Regras para análise de sementes. Brasília: Ministério da Agricultura, Pecuária e Abastecimento, Secretaria de Defesa Agropecuária, 395 p. Livestock and Supply.

Caratti, F., Lamego, F.P., Bianchi, M.A., Farias, H., Silva, B.M. and Cechin. J. (2018). Interference of volunteer corn on soybean cultivars growth and yield. Comunicata Scientiae, 9, 637-648. https://doi.org/10.14295/cs.v9i4.1961

Carciochi, W.D., Schwalbert, R., Andrade, F.H., Corassa, G.M., Carter, P., Gaspar, A.P., Schmidt, J. and Ciampitti, I.A. (2019). Soybean seed yield response to plant density by yield environment in North America. Agronomy Journal, 111, 1923-1932. https://doi.org/10.2134/ agronj2018.10.0635

Chahal, J., and Jhala, A.J. (2015). Herbicide programs for control of glyphosate-resistant volunteer corn in glufosinate-resistant soybean. Weed Technology, 29, 431-443. https://doi.org/10.1614/WT-D-15-00001.1

Chekan, J.R., Ongpipattanakul, C., Wright, T.R., Zhang, B., Bollinger, J.M., Rajakovich, L.J., Krebs, C., Cichillo, R.M. and Nair, S.K. (2019). Molecular basis for enantioselective herbicide degradation imparted by aryloxyalkanoate dioxygenases in transgenic plants. Proceedings of the National Academy of Sciences, 116, 13299-13304. https://doi.org/10.1073/pnas.1900711116 
Derre, L.O., Daltoé, J.A., Sarubo, V. and Abrantes, F.L. (2017). Influência do tamanho de sementes na germinação e vigor inicial da soja (Glycine max). Colloquium Agrariae, 13, 100-107. https://doi.org/10.5747/ca.2017.v13.nesp.000179

Duke, S.O. (2020). Glyphosate: environmental fate and impact. Weed Science, 68, 201-207. https://doi.org/10.1017/wsc.2019.28

Ebone, L.A., Caverzan, A., Tagliari, A., Chiomento, J.L.T., Silveira, D.C. and Chavarria, G. (2020). Soybean seed vigor: Uniformity and growth as key factors to improve yield. Agronomy, 10, 545. https://doi.org/10.3390/agronomy10040545

Giraudo, M.E. (2020). Dependent development in South America: China and the soybean nexus. Journal of Agrarian Change, $20,60-78$. https://doi.org/10.1111/joac.12333

Gonzalez, D.O., Church, J.B., Robinson, A., Connell, J.P., Sopko, M., Rowland, B., Woodall, K., Larsen, C.M. and Davies, J.P. (2018). Expression characterization of the herbicide tolerance gene Aryloxyalkanoate Dioxygenase (AAD-1) controlled by seven combinations of regulatory elements. BMC Plant Biology, 18, 1-13. http://dx.doi.org/10.1186/s12870-018-1227-3

Han, C., Yin, X., He, D. and Yang, P. (2013). Analysis of proteome profile in germinating soybean seed, and its comparison with rice showing the styles of reserves mobilization in different crops. PLoS One, 8, e56947. https://doi.org/10.1371/journal.pone.0056947

Harre, N.T. and Young, B.G. (2020). Early-season nutrient competition between weeds and soybean. Journal of Plant Nutrition, 43, 18871906. https://doi.org/10.1080/01904167.2020.1750648

Kandasamy, S., Weerasuriya, N., Gritsiouk, D., Patterson, G., Saldias, S., Ali, S. and Lazarovits, G. (2020). Size variability in seed lot impact seed nutritional balance, seedling vigor, microbial composition and plant performance of common corn Hybrids. Agronomy, $10,157$. https://doi.org/10.3390/agronomy10020157

Kukorelli, G., Reisinger, P. and Pinke, G. (2013). ACCase inhibitor herbicides - selectivity, weed resistance and fitness cost: A review. International Journal of Pest Management, 59, 165-173. https://doi.org/10.1080/09670874.2013.821212

Marca, V., Procópio, S.O., Silva, A.G. and Volf, M. (2015). Chemical control of glyphosate-resistant volunteer maize. Revista Brasileira de Herbicidas, 14, 103-110. http://dx.doi.org/10.7824/rbh.v14i2.408

Marcos-Filho, J. (2015). Fisiologia de sementes de plantas cultivadas. Londrina: ABRATES.

Mckenzie-Gopsill, A.G., Lee, E., Lukens, L. and Swanton, C.J. (2016). Rapid and early changes in morphology and gene expression in soyabean seedlings emerging in the presence of neighbouring weeds. Weed Research, 56, 267-273. https://doi.org/10.1111/wre.12207

Nakagawa, J. (1999). Testes de vigor baseados no desempenho das plântulas. In: F.C. Krzyzanowski, R.D. Vieira, and J.B. França-Neto (Eds.), Vigor de sementes: conceitos e testes (p. 2-24). Londrina: ABRATES.

Nandula, V.K., Riechers, D.E., Ferhatoglu, Y., Barrett, M., Duke, S.O., Dayan, F.E., Goldberg-Cavalleri, A., Tétard-Jones, C., Wortley, D.J., Onkokesung, N., Brazier-Hicks, M., Edwards, R., Gaines, T., Iwakami, S., Jugulam, M. and Ma, R. (2019). Herbicide metabolism: crop selectivity, bioactivation, weed resistance, and regulation. Weed Science, 67, 149-175. https://doi.org/10.1017/wsc.2018.88

Novakoski, F.P., Albrecht, L.P., Albrecht, A.J.P., Silva, A.F.M., Mattiuzzi, M.D., Mundt, T.T., Kashivaqui, E.S.F. and Wagner, F.G. (2020). Postemergence application of herbicides and growth regulators on soybean growth and agronomic performance. Journal of Crop Science and Biotechnology, 23, 253-258. https://doi.org/10.1007/s12892-020-00033-w

Pertile, M., Cechin, J., Zimmer, V., Agostinetto, D. and Vargas, L. (2018). Interference of volunteer corn in glyphosate resistant soybean and chemical control in different phenological stages. Bioscence Journal, 34, 1248-1257. https://doi.org/10.14393/BJ-v34n5a2018-39462

Petter, F.A., Sima, V.M., Fraporti, M.B., Pereira, C.S., Procópio, S.O. and Silva, A.F. (2015). Volunteer RR corn management in Roundup Ready soybean-corn succession system. Planta Daninha, 33, 119-128. https://doi.org/10.1590/S0100-83582015000100014

Piasecki, C. and Rizzardi, M.A. (2018). Economic threshold of volunteer corn GR in soybean as a function of emergence time and origin of corn. Planta Daninha, 36, e018177264. https://doi.org/10.1590/s0100-83582018360100092 
Rao, N.K., Dulloo, M.E. and Engels, J.M.M. (2017). A review of factors that influence the production of quality seed for long-term conservation in genebanks. Genetics Resources and Crop Evolution, 64, 1061-1074. https://doi.org/10.1007/s10722-016-0425-9

Skelton, J.J., Simpson, D.M., Peterson, M.A. and Riechers, D.E. (2017). Biokinetic analysis and metabolic fate of 2, 4-D in 2, 4-D resistant soybean (Glycine max). Journal of Agricultural and Food Chemistry, 65, 5847-5859. https://doi.org/10.1021/acs.jafc.7b00796

Striegel, A., Lawrence, N.C., Knezevic, S.Z., Krumm, J.T., Hein, G. and Jhala, A.J. (2020). Control of glyphosate/glufosinate-resistant volunteer corn in corn resistant to aryloxyphenoxypropionates. Weed Technology, 34, 309-317. https://doi.org/10.1017/wet.2020.41

Tecle, B., Dacunha, A. and Shaner, D.L. (1993). Differential routes of metabolism of imidazolinones: Basis for soybean (Glycine max) selectivity. Pesticide Biochemistry and Physiology, 46, 120-130. https://doi.org/10.1006/pest.1993.1043

Wright, T.R., Shan, G., Walsh, T.A., Lira, J.M., Cui, C., Song, P., Zhuang, M., Arnold, N.L., Lin, G., Yau, K., Russel, S., Cicchillo, R.M., Peterson, M.A., Simpson, D.M., Zhou, N., Ponsamuel, J. and Zhang, Z. (2010). Robust crop resistance to broadleaf and grass herbicides provided by aryloxyalkanoate dioxygenase transgenes. Proceedings of the National Academy of Sciences, 107, 20240-20245. https:// doi.org/10.1073/pnas.1013154107

Zandoná, R.R., Agostinetto, D., Silva, B.M., Ruchel, Q. and Fraga, D.S. (2018). Interference periods in soybean crop as affected by emergence times of weeds. Planta Daninha, 36, e01816936. http://doi.org/10.1590/s0100-83582018360100045 